\title{
マイコン制御によるパルス電析 $\mathrm{Co} / \mathrm{Cu}$ 膜の 電気抵抗および磁性*1
}

\section{宝賀 剛*2 山田昭弥*2 上田勇治}

室蘭工業大学工学部電気電子工学科

J. Japan Inst. Metals, Vol. 64, No. 9 (2000), pp. 739-742

(C) 2000 The Japan Institute of Metals

\section{Resistivity and Magnetism of Co/Cu Films Produced by Computer Controlled Pulse Electrodeposition*1}

Takeshi Houga*2, Akihiro Yamada ${ }^{* 2}$ and Yuji Ueda

Muroran Institute of Technology, Muroran 050-8585

A pulse electrodeposition technique using a pulse generator circuit has been utilized to produce multilayer films with control on an atomic scale. The pulse generator was designed to control the deposition time within the range of $0.1 \mathrm{~ms}$. The magnetoresistance ratio for the multilayer film controlled on an atomic scale had a maximum value of about $9.5 \%$ at the stacking number of 110 . The temperature dependence of magnetization for the films with thin layers shows superparamagnetic behavior.

(Received April 25, 2000; Accepted July 18, 2000)

Keywords: magnetism, electric resistance, multilayers, pulse electrodeposition, cobalt/copper

\section{1. 緒言}

近年の薄膜作製技術の飛躍的な進歩により，物質を原子オ ーダーで制御した材料の研究，開発が盛えに行われるよらに なり，これらの物質が従来にない物性执よび機能性材料とし ての特性るつこが期待され，応用上の観点から注目され ている.

これらの薄膜材料の作製は，真空蒸着法やスパッタリング 法などといった気相成長法が主であるが1-3)，我々は，以前 より液相からの電気化学的成長法である電析法により試みて きた，電析法は，適当な溶液や電析条件を見いだすことによ り，電位または電流の值のみの調節で任意に組成を変化させ

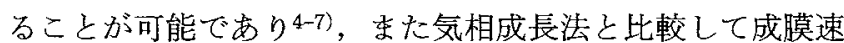
度や膜厚のコントロールが原理的にしやすいという薄膜作製 上の利点を有している。一般の溶融法では相分離し合金化が 困難な金属の組久合わせに打いても，電析法は室温程度での 析出のため, $\mathrm{pH}$ や通過電気量など各種電析条件の調節によ り非平衡な固溶型合金作製の可能性をもっている。なた，多 層膜の作製に和いて，パルス電位を時間的飞変化(パス波 形制缶)させ，各層厚を極限的に薄くすることによっても固 溶型の合金を得ることがでさる。すなわち，一層あたりの平 均膜厚が一原子析出以下になれば，必然的に固溶型合金に近 い状態を実現できることになる。しかしながら，電析法を用
いた多層膜作製に関する研究報告は少なく，さらに各層を原 子オーダーで制御したものの電気的执よび磁気的性質などの

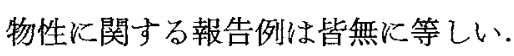

我々は，パルス電析法に上り多層膜を作製するにあたり， 各層厚を原子オーダーで制御するため，通過電気量を微少に 制御可能なマイコンを用いたパルス発生回路の製作を行っ た.この回路では，作製する多層膜の各層厚をともに变化さ せることや，一方の金属層厭を一定にした状熊でもら一方の みを変化させるといった制御が可能であり，今回は特に強磁 性，非磁性金属の組合せに扣いて各層厚を極端に薄くしたも のについての作製を試みた。さらに，これらの薄膜に执い て，多層状態と強制固溶状態に拈ける磁性や電気后導に関す る物性について検討を行った。

\section{2. 実 験 方 法}

電析溶液に流酸浴 $\left(\mathrm{CoSO}_{4} \cdot 7 \mathrm{H}_{2} \mathrm{O}, \mathrm{CuSO}_{4} \cdot 5 \mathrm{H}_{2} \mathrm{O}, \mathrm{Na}_{3} \mathrm{C}_{6}\right.$ $\mathrm{H}_{5} \mathrm{O}_{7}, \mathrm{NaCl}$ ) 用い， $\mathrm{pH} 5$ とした。基板は，ガラス上に $15 \mathrm{~nm}$ のCuを蒸着したものを用いた。電析は $3 \sim 200 \mathrm{~A} / \mathrm{m}^{2}$ の範囲の電流密度で行った。組成分析は虽光 X 線分析扣よ び原子吸光分析により行った．磁気抵抗比は㨁流四端子法に より，試料に最大 $1.67 \mathrm{MA} / \mathrm{m}$ までの磁界を印加し室温に拉 いて湘定した。磁気特性はVSM 和よびrf-SQUIDにより $300 \mathrm{~K}$ から $5 \mathrm{~K}$ までの温度範囲で測定した。

\footnotetext{
*1 2000年 3 月 30 日日本金属学会春期大会行小て発表

*2 室蘭工業大学大学院生 (Graduate Student, Muroran Institute of Technology)
} 


\section{3. パルス電析法による多層膜および合金膜の作製}

Fig. 1 亿作製したパルス発生回路の概略を示す．回路は大 きく分けて，マイコン，D-A コンバータ，定電流回路の 3 つの部分から構成されている．以下にその主な役割と性能见 ついて説明する.

\section{1 マイコン}

時間拉よび電圧を制御するためのマイコン部分には Z80CPU を搭載したクロック周波数 $5 \mathrm{MHz}$ のマイコンボー ドを用いた。委た，このボード上のメもりに出力信号扩よ び，立の出力時間を制御するためのプログラムを入力した． 今回作製したプログラムに和いては，実際化作製する薄膜の 膜厚を考慮し，時間の分解能が $0.1 \mathrm{~ms}$ になるように設定し た.

\section{$3.2 \mathrm{D}-\mathrm{A}$ コンバータ}

マイコンからの出力はディジタル量であるため，0 または $5 \mathrm{~V}$ の電圧值しか取り得ず，これ以外の值を出力させるため には，複数のディジタル出力を合わせて，アナログ量に变換 する必要がある。また，薄膜の膜厚を原子オ一ダ一で制御す るためには，この值をできるだけ細かく設定する必要があ り，そのためこのマイコン部分の出力に 10 打よび $20 \mathrm{k} \Omega$ の 2 種類の抵抗を用い， $\mathrm{R}-2 \mathrm{R}$ ラダー型 $\mathrm{D}-\mathrm{A}$ コンバータを構 成した.

\section{3 定電流回路}

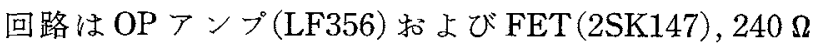
の抵抗から構成されている. FETのソース側を陰極とし， 試料を作製する基板を接続した。陽極は外部電源の十出力に 接続し，一出力側は接地している，外部電源からの電圧を $30 \mathrm{~V}$ とし，FETのソース，ドレイン間を流れる電流をゲー 卜電圧を調節することにより，約 0〜20 mA 範囲で，分 解能約 $0.08 \mathrm{~mA}$ の電流制御が可能となった.

この装置において多層膜を作製する場合のプログラムのフ ローチャートをFig. 2 亿示す．このプログラムでは堆積さ せる金属の析出電位化対応した電流が，それぞれの膜厚に対 応させて設定した時間で交互に流れる上うな構造になって和 りここれにより 2 つの異なる金属イオンを含さ溶液に括い て，パルス電流を加兄多層膜の作製を行った。この多層膜作 製において，各電流に対応したパルス幅を極端に狭くすると 平均層厚が減少し，この厚さが 1 原子層以下になると平面

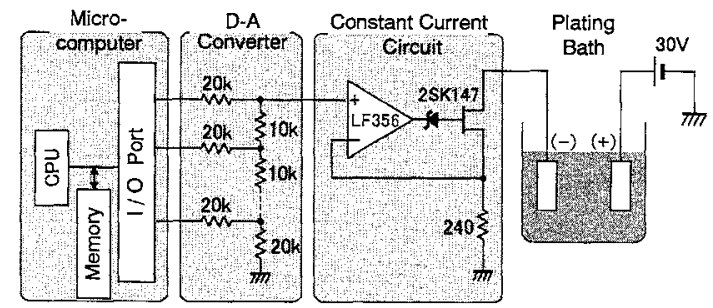

Fig. 1 Diagram of a pulse generator circuit.
的な層の形成はありえず，不連続な状態や島状に原子が堆積 することになる．即ちこのような異なる原子層を交互に堆積 することにより，微粒子分散型合金や，究極的には固溶型合 金が作製されることになる。このとき，2つの異なる電流を 出力させる時間を同時に，さらに同じ割合で減少させた場合 には，膜全体としての金属原子の比(組成比) 一定に保ちつ つ，内部の層状態を変化させることが可能となり，また，一 方の時間の久を減少させることにより，多層膜の強磁性抢よ び非磁性層厚依存性や，希薄合金の上らな膜の作製も可能と なる。

以上のことをるとに，本研究に和いてはFig. 3 のような 組成一定のもとでの多層膜から合金膜への移行過程での物性

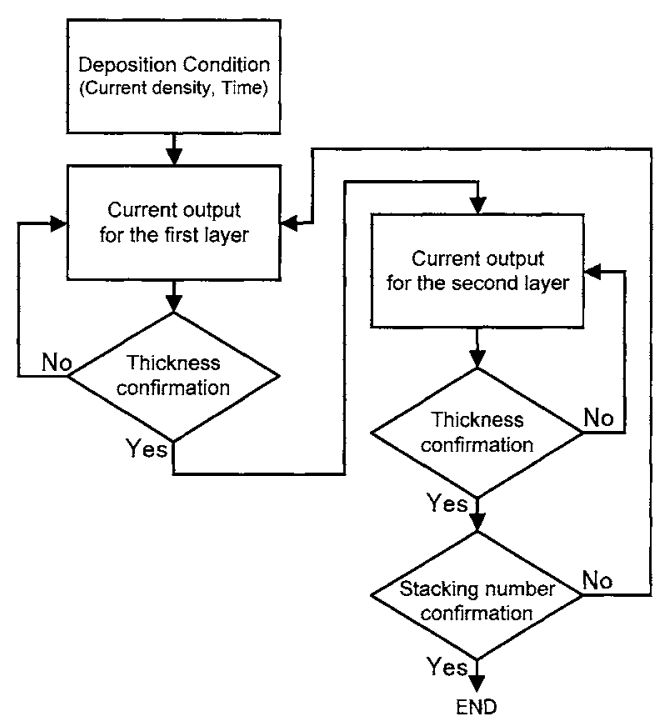

Fig. 2 Flowchart of multilayered film preparation.

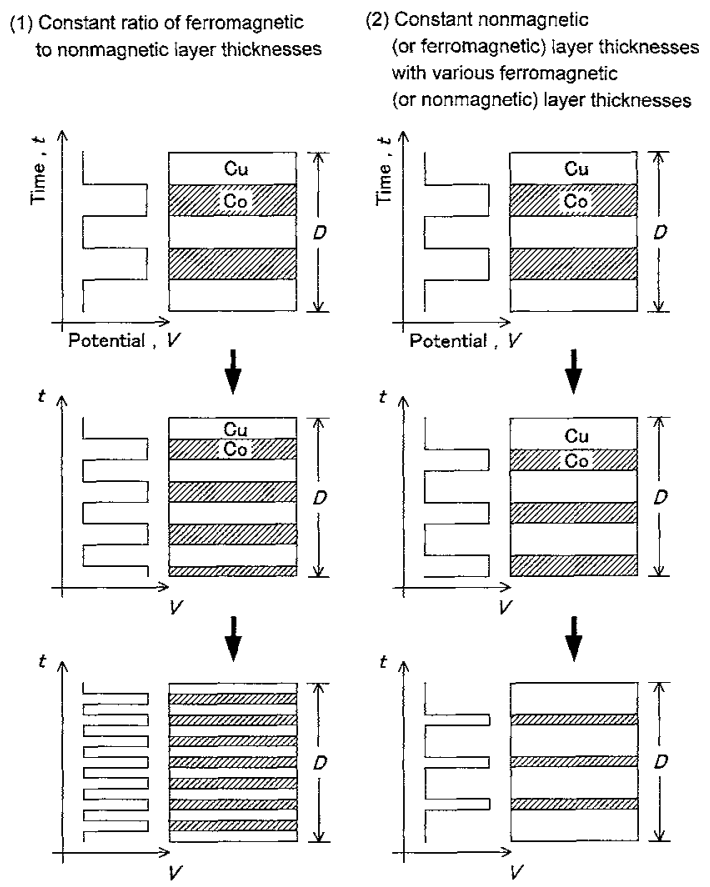

Fig. 3 Schematic diagram of the effect of the electrodeposition pulse width on the microstructure of the films. 
を調べた。また，全膜厚执よび組成此をとれぞれ $220 \mathrm{~nm}$ ， 18 at\% Co 一定とし膜の作製を行った。

ここで，全膜厚を $D$, 積層数を $n$ とすると，

$$
D=\sum_{m=1}^{n} t_{\mathrm{a}}^{(m)}+\sum_{m=1}^{n} t_{\mathrm{b}}^{(m)}
$$

$t_{\mathrm{a}}^{(m)}$ はa層の第 $m$ 層目であり

$$
t_{\mathrm{a}}^{(i)}=t_{\mathrm{a}}^{(j)}, t_{\mathrm{b}}^{(i)}=t_{\mathrm{b}}^{(j)}(i \neq j)
$$

とすると

$$
D=n\left(t_{\mathrm{a}}+t_{\mathrm{b}}\right)
$$

また， $\rho_{\mathrm{a}}, \rho_{\mathrm{b}}$ をそれぞれ $\mathrm{a}, \mathrm{b}$ 金属の密度とし，

$$
\rho_{\mathrm{a}} \sum_{m=1}^{n} t_{\mathrm{a}} \mid \rho_{\mathrm{b}} \sum_{m=1}^{n} t_{\mathrm{b}}=k(=\text { const. })
$$

とする。

この $k$ は $\mathrm{a}$ 金属と $\mathrm{b}$ 金属の比を示して括り，すなわち作 製される多層膜の各層の組成等を考慮した全体の組成比を示 している. 以下，実験結果はこの $n$ に対して示す.

\section{4. 実 験 結 果}

Fig. 4 亿積層数 $n$ に対する室温に打ける抵抗率 $\rho$, 磁界印 加 $(1.67 \mathrm{MA} / \mathrm{m})$ による抵抗率の変化 $\Delta \rho$ 和よび磁気抵抗 (MR) 比を示す. $\rho$ が $n$ の増加とともに增加するのに対し， $\Delta \rho$ はR 比と同様に $n=110$ 付近で極大を示し, MR 比の 最大值は約 $9.5 \%$ 示した。この極大を示す強磁性 Co 層の 平均膜厚梳, Co 層が連続的平面配列加ら断続的不連続成長 をする境界付近に位置しているため，更に積屏数を増加させ ると, 一原子層以下の平均層厚となるため, 不連続的成長と なり，すなわち，钘粒子化するものと考光られる。しかし， 微粒子合金に颃いては，完全に固溶された状態よりる，ある 程度強磁性的な微粒子が適当な粒径および分布状態で存在す るとき，大きな磁気抵抗が得られて扣り ${ }^{5,8)}$ ，積層数を増加 させたとき，この粒径扣よび分布が必ずしも最適の条件にな っているとは言えず，MR 比は減少しているものと考えられ

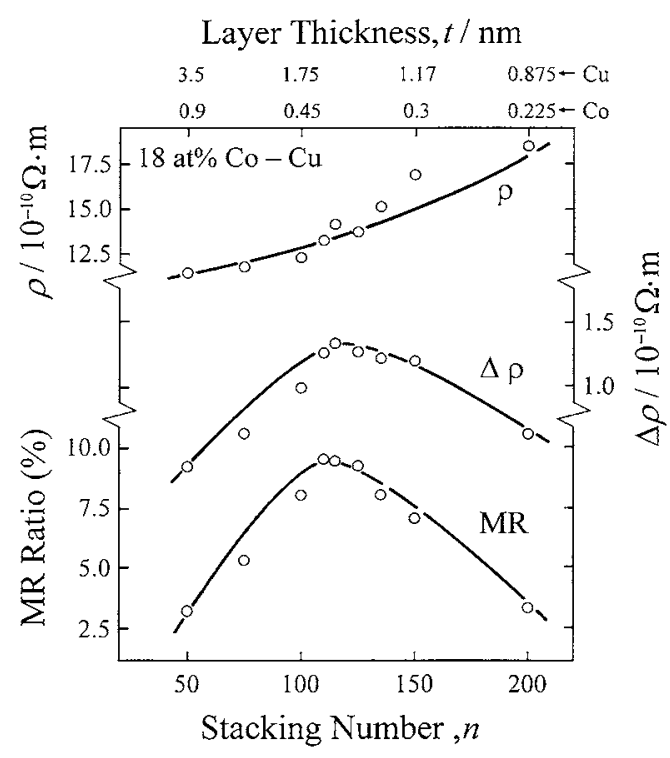

Fig. 4 Stacking number $(n)$ dependence of the resistivity $(\rho)$, change in the resistivity $(\Delta \rho)$ and MR ratio of the films.
る。すなわち，作製したパルス発生回路により薄膜の内部状 態を変化させることがでさていると予想される。

Fig. 5 は Fig. 4 の各点における $\Delta \rho / \rho$ の磁界依存性および 磁化曲線を示す. $n=50$ に扣いては, 弱磁界でも MR曲線 が飽和しやすい㑯向を示すが，MR 比が最大值を示した付近 である $n=125$ では $1.67 \mathrm{MA} / \mathrm{m}$ 程度の磁界でも飽和して㧊 らず，全体的にnの増加に伴い飽和しにくい傾向となって いる.

また磁化曲線は $n=50$ 飞执いて強磁性的であるが，nの 增加に伴い角型比が悪くなり飽和しにくく、, 存性とも対応している。

これらの結果は, 強磁珄層が薄くなることにより微粒子に 近づき, 比較的厚い層の強磁性状態からスーパーパラ的な強 磁性徽粒子部分が多い状熊が作製されていることを示唆して いる。

一般に，スーパーパラ的な挙動を示す系は，希薄合金に特 いて見られるスピングラスとは異なり，熱擾乱している微粒 子の磁化が低温に抏いてその粒子の磁化容易方向に凍結され 磁化の極大が見られる。この極大を示す温度はブロッキング

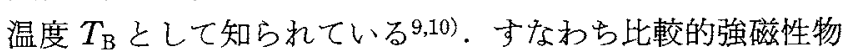
質が多く含まれるような系に持いて， $T_{\mathrm{B}}$ 以上の温度ではス ーパーパラ的であることを示して和り，ピークが見られると いらことは微粒子《なっていることが考えられる。またこの $T_{\mathrm{B}}$ は強磁性微粒子の粒径に対応すると考えられている ${ }^{9,10)}$.

Fig. 6 はこのブロッキング温度 $T_{\mathrm{B}}$ を積層数 $n$ に詨し示し たものである，nの増加に対し， $T_{\mathrm{B}}$ は減少する傾向を示す ことから, 強磁性微粒子の粒径がより微細になっていること が考光られる。

また挿入図は，磁界 $H=7.96 \mathrm{kA} / \mathrm{m}$ で測定したゼ口磁場 冷却 $(\mathrm{ZFC})$ 扎よび磁場中冷却 $(\mathrm{FC})$ 磁化の温度依存性を, $n=$ 100 扎よび200の膜について示したものであり，n=200では より低温側にピータが見られている.図には示していない が， $n=50$ の膜は測定温度範囲に扎いてピークが見られな い.これは厚い強磁性層が形成され， $T_{\mathrm{B}}$ は $300 \mathrm{~K}$ 以上に存 在することが予想される。更に，nが125以上の膜に执いて 室温付近は $T_{\mathrm{B}}$ よりあ高温であることから, 室温付近ではス

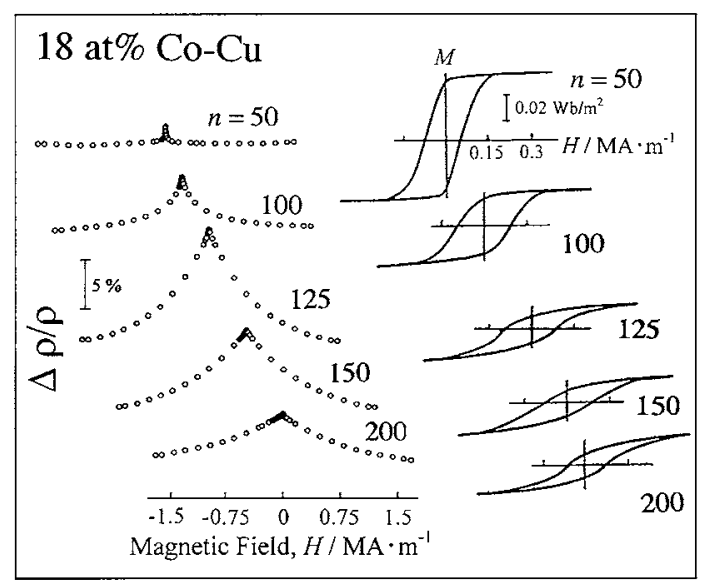

Fig. 5 Magnetic field dependence of the $\Delta \rho / \rho$ and magnetization curves of the films. 


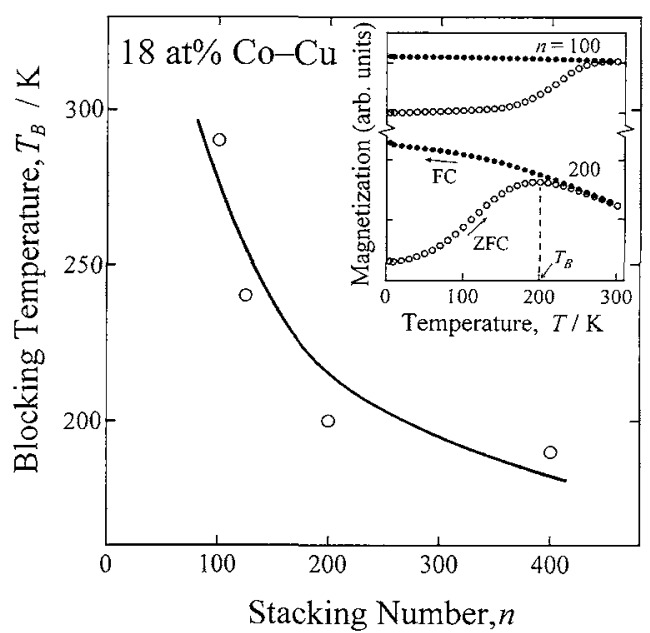

Fig. 6 Stacking number dependence of the blocking temperature $\left(T_{\mathrm{B}}\right)$ of the films. Inset shows the temperature dependence of the zero-field-cooled (ZFC) and field-cooled (FC) magnetization at $7.96 \mathrm{kA} / \mathrm{m}$ for the films of $n=100$ and 200 .

ーパーパラ的であることが言え, Fig. 5 の磁化曲線とも一致 した傾向を示す。

\section{5. 結論}

マイコンを用いたパルス発生回路の作製により，0.1 ms までの短い時間間隔の制御が可能となった。この装置を用い
たパルス電析により $\mathrm{Co} / \mathrm{Cu}$ 多層膜の平均層厚が原子オーダ 一 (0.1 0.4 nm 程度) で制御された膜の作製が可能であっ た. 膜全体の組成一定のもとで層厚を原子オーダーで極端に 薄く制御した膜に拈いて，MR 比は極大を示しその極大値は $n=110$ に和いて $9.5 \%$ を示した，平均層厚が薄い膜に和い て, 磁化の温度依存性はスーパーパラ的な挙動を示し, 比較 的微細に混合した微粒子状熊の膜の作製が可能であった。

文献

1) S. S. P. Parkin, R. Bhadra and K. P. Roche: Phys. Rev. Lett., 66(1991), 2152-2155.

2) C. L. Chien, J. Q. Xiao and J. S. Jiang: J. Appl. Phys., 73(1993), 5309-5314.

3) K. Takanashi, J. Park, T. Sugawara, K. Hono, A. Goto, H. Yasuoka and H. Fujimori: Thin Solid Films, 275 (1996), 106110 .

4) M. Alper, K. Attenborough, R. Hart, S. J. Lane, D. S. Lashmore, C. Youness and W. Schwarzacher: Appl. Phys. Lett., 63(1993), 2144-2146.

5) Y. Ueda and M. Ito: Jpn. J. Appl. Phys., 33 (1994), L1403L1405.

6) Y. Ueda, N. Hataya and H. Zaman: J. Magn. Magn. Matt., 156(1996), 350-352.

7) S. Kainuma, S. Ishikura and K. Hisatake: J. Magn. Soc. Jpn., 21(1997), 557-560.

8) Y. Ueda and S. Ikeda: Mater. Trans., JIM, 36(1995), 384-388.

9) G. T. Rado and H. Suhl: Magnetism III, Academic press, New York, (1963), pp. 271-298.

10) T. Bitoh, K. Ohba, M. Takamatsu, T. Shirane and S. Chikazawa: J. Phys. Soc. Jpn., 62(1993), 2583-2586. 